(Civil Engineeering, Elektrical Engineeering and Industrial Engineeering)

Vol. 16, No : 1, April 2019 , p-ISSN:1907-5243, e-ISSN: 2655-8416

\title{
TINGKAT BEBAN KERJA MENTAL KARYAWAN PADA LAYANAN BUSINESS, GOVERNMENT, ENTERPRISE (BGES) BOGOR PT. TELKOM INDONESIA BERDASARKAN METODE NASA-TLX
}

\author{
Monika Nadya Aprillia ${ }^{1}$, Rida Zuraida ${ }^{2 *}$ \\ Industrial Engineering Department, Faculty of Engineering, Universitas Bina Nusantara, \\ Jakarta Indonesia 11480 \\ ${ }^{1}$ monika.hariadi@yahoo.com; ${ }^{2}$ rzuraida@binus.ac.id
}

\begin{abstract}
PT. Telkom Indonesia is one of the telephone and internet service providers in Indonesia. There are still many schools without internet facilities, so PT. Telkom provides education and offers this services. Business, Government, Enterprise (BGES) PT. Telkom in Bogor is a division that offers this service. The large number of schools without internet facilities in Bogor as well as the service coverage area of BGES encourages a research on the mental workload of employees in this division. Workload assessments were carried out on 12 employees in the Account Manager (AM) Government, AM Pro, and organic AM using the NASA-TLX method. The result is that the workloads in all three parts of the AM are categorized as high. The results of the assessment show that the mental workload in the three AM sections is categorized as high (>61). The highest workload found in Temporal Demand (PD), Effort (E), and frustration $(F)$. This is mainly due to the large number of schools that must be visited and the busy schedule. Adding employees, arranging visits to customers and scheduling assignments out of town can be done to balance the workload felt by current employees.
\end{abstract}

Keywords: Workload, Workload Dimension, NASA-TLX

\section{PENDAHULUAN}

Kemajuan teknologi di berbagai aktivitas manusia telah mengubah pola kerja serta cara manusia menangani masalah dan pekerjaan dan menjadikannya lebih efisien termasuk di bidang telekomunikasi [1]. Kemajuan di bidang ini yang paling terasa berupa teknologi interconnected network (internet). Internet memungkinkan masyarakat memperoleh informasi digital baik lokal, nasional, maupun global dengan cepat dan mudah. Kemudahan ini dirasakan juga di sektor pendidikan, terutama dalam masa pandemi ini. Adanya internet, memungkinkan penyelenggaraan secara daring untuk pembelajaran baik di tingkat pendidikan dasar hingga tinggi sejak April 2020 [2].

Akses internet di berbagai sekolah saat ini belum merata, sehingga penyelenggaraan pendidikan yang memanfaatkan internet belum terlaksana dengan baik. Sekolah-sekolah perkotaan sebagian besar telah memiliki fasilitas internet yang sesuai, sedangkan sekolah daerah kabupaten dan pelosok belum menikmati layanan internet dan telepon.

PT. Telkom Indonesia merupakan salah satu penyelenggara layanan internet dan telepon di Indonesia untuk sekolah swasta dan negeri. PT.Telkom Indonesia, divisi Business, Government, Enterprise (BGES) Bogor menangani pelanggan pada segmen edukasi di wilayah Kota Bogor, Kabupaten Bogor, dan Depok. Untuk daerah Kabupaten Bogor layanan internet dan telepon baru tersedia pada Sebagian kecil sekolah-sekolah. Faktor yang menyebabkannya 
adalah belum adanya pembangunan ODP (Optical Distribution Point) di daerah sekitar sekolah sehingga layanan telepon dan internet tidak dapat digunakan.

Sistem pelayanan pada divisi BGES (Business, Government, Enterprise) Bogor terdiri dari presales, sales, provisioning, dan aftersales. Kegiatan dimulai dari sales, yaitu data calon pelanggan dikumpulkan terlebih dahulu berdasarkan segmen pelanggan yang telah ditetapkan perusahaan. Sebagai contoh dari segmen edukasi, data sekolah di suatu kecamatan dikumpulkan secara lengkap dari alamat, nomor telepon dan lain-lain. Taha berikutnya dilakukan call atau visit untuk memberikan penawaran layanan serta solusi sampai diperoleh kesepakatan antara dua pihak. Sekolah sebagia konsumen merupakan area yang dilayani oleh bagian edukasi, dan setiap sekolah yang mendapat pelayanan akan memiliki business account untuk mengakses layanan dan sebagai identitas dalam melakukan pembayaran. Proses pelayanan yang dibahas merupakan bagian tugas dari seorang account manager.

Tugas utama dari account manager yaitu mengontrol aftersales setiap pelanggan berupa kegiatan caring. Kegiatan ini berupa layanan perpanjangan kontrak, troubleshooting atau layanan jika ada gangguan, upgrade/downgrade layanan, serta pemberhentian layanan.

PT. Telkom dalam memberikan pelayanan dituntut untuk terus meningkatkan produktivitasnya. Hal ini tidak terlepas dari sumber daya manusia yang optimal untuk melakukan proses pelayanan. Sumber daya manusia merupakan aset penting bagi perusahaan yang harus dikelola dengan baik [3]. Begitu pula dengan karyawan di BGES Bogor yang menjadi studi kasus.

Produktivitas mempunyai dua dimensi, yaitu efektivitas yang mengarah pada pencapaian unjuk kerja yang maksimal berupa pencapaian target. Pencapaian ini berkaitan dengan kualitas, kuantitas dan waktu. Dimensi kedua adalah efisiensi yaitu upaya membandingkan input dengan realisasi penggunaannya atau bagaimana pekerjaan tersebut dilaksanakan [4]. Tingkat efektivitas dan efisiensi salah satunya dipengaruhi oleh beban kerja yang dirasakan oleh karyawan [5]. Pada karyawan BGES bagian edukasi, beban kerja berhubungan erat dengan jumlah data sekolah yang menjadi target edukasi, proses call atau visit, hingga terlaksananya layanan dan pemberian layanan aftersales.

Beban kerja mental dapat dipandang sebagai variabel bebas eksternal dalam tuntutan tugas, dan beban kerja mental didefinisikan sebagai sebuah interaksi antara tuntutan tugas dengan kemampuan manusia atau sumber daya [6]. Beban kerja mental berlebih dapat menjadi stressor bagi karyawan. Stres adalah kondisi fisik dan psikologis yang dipengaruhi oleh adaptasi seseorang dengan lingkungannya [7]. Stres dapat berupa upaya menghindar atau menghadapi tuntutan lingkungannya. Stres kerja dapat berdampak buruk pada kondisi kejiwaan apabila tidak dilakukan penanggulangan [8]. Pengukuran beban kerja dapat dilakukan dengan menggunakan metoda NASA-TLX. Metoda ini mengukur beban kerja berdasarkan 6 dimensi ukuran beban kerja yaitu Mental Demand, Physical Demand, Temporal Demand, Performance, Effort dan Frustration Level. Langkah-langkah pengukuran beban kerja mental dengan menggunakan NASA- TLX adalah sebagai berikut [9] :

82 | Tingkat Beban Kerja Mental Karyawan Pada Layanan Business, Government, Enterprise (Bges) Bogor Pt. Telkom Indonesia Berdasarkan Metode Nasa-Tlx 


\section{Pembobotan hasil kuesioner}

Pembobotan hasil kuesioner menggunakan enam indikator untuk mengetahui besar beban kerja mental yaitu Mental Demand (MD), Physical Demand (PD), Temporal Demand (TD), Performance $(P)$, Frustration level $(F R)$. Pembobotan merupakan tahap pemberian bobot pada 15 pasangan indikator yang diisi responden dengan melingkari salah satu pasangan indikator yang lebih dominan (Gambar 1).

\begin{tabular}{|c|c|c|}
\hline $\begin{array}{l}\text { Kebutulhan waktu } \\
\text { atau } \\
\text { Tinekat Frestasi }\end{array}$ & $\begin{array}{c}\text { Kebutuhan Fisik } \\
\text { atau } \\
\text { Performansi }\end{array}$ & $\begin{array}{l}\text { Performansi } \\
\text { atau } \\
\text { Tingkat frustasi }\end{array}$ \\
\hline $\begin{array}{l}\text { Rebutuluas waktu } \\
\text { atas }\end{array}$ & $\begin{array}{c}\text { Tingkat usaha } \\
\text { atma }\end{array}$ & $\begin{array}{c}\text { Tingkat usaha } \\
\text { atam }\end{array}$ \\
\hline Tingkat Usaha & Performansi & Kebutuhas fisak \\
\hline $\begin{array}{c}\text { Kebutuhan } \\
\text { Mestal } \\
\text { atas } \\
\text { Tingkat Usahs }\end{array}$ & $\begin{array}{l}\text { Performansi } \\
\text { atas } \\
\text { Keboruhan } \\
\text { mental }\end{array}$ & $\begin{array}{c}\text { Tingkat Frustasi } \\
\text { atau } \\
\text { Kebuniban } \\
\text { mental }\end{array}$ \\
\hline $\begin{array}{l}\text { Kebutuhan mental } \\
\text { atati } \\
\text { Kebutuhan Fisik }\end{array}$ & $\begin{array}{l}\text { Performansi } \\
\text { atas } \\
\text { Ketrutuhas } \\
\text { walsu }\end{array}$ & $\begin{array}{c}\text { Tingkat frustast } \\
\text { atas } \\
\text { Tingkat nsaha }\end{array}$ \\
\hline $\begin{array}{c}\text { Kebutuhan waktii } \\
\text { gtas } \\
\text { Kebuttulan } \\
\text { Mental }\end{array}$ & $\begin{array}{c}\text { Kebratuhan fisik } \\
\text { atau } \\
\text { Kebututhan } \\
\text { walitu }\end{array}$ & $\begin{array}{l}\text { Kebutuhun fisik } \\
\text { atan } \\
\text { Tingkat frustasi }\end{array}$ \\
\hline
\end{tabular}

Gambar 1. Perbandingan Berpasangan Metode NASA-TLX [10]

2. Pengkategorian penilaian beban kerja

Skor beban kerja yang diperoleh dapat diintepretasikan sebagai berikut:

Tabel 1. Interval pengkategorian beban kerja mental

\begin{tabular}{|c|l|c|}
\hline \multicolumn{1}{|c|}{ No } & \multicolumn{1}{|c|}{ Kategori } & Skala Interval \\
\hline 1. & Sangat Rendah & $0-20$ \\
\hline 2. & Rendah & $21-40$ \\
\hline 3. & Sedang & $41-60$ \\
\hline 4. & Tinggi & $61-80$ \\
\hline 5. & Sangat Tinggi & $81-100$ \\
\hline
\end{tabular}

3. Pembobotan Hasil Kuesioner

Pada tahap ini, karyawan sebagai responden diminta untuk memilih dengan cara memberikan tanda centang $(\sqrt{ })$ atau menulis salah satu dari dua faktor yang lebih dominan mempengaruhi beban kerja mereka.

4. Pemberian Rating atau Peringkat

Pemberian rating atau peringkat merupakan tahap setelah pembobotan ditahap sebelumnya. Pada tahap ini, pekerja di lantai produksi diminta untuk memberikan rating antara 1-100 untuk setiap faktor sesuai dengan beban kerja yang dirasakan pekerja. 


\section{Perhitungan Weigted Workload (WWL)}

Nilai WWL merupakan nilai beban kerja mental yang dirasakan oleh pekerja Penentuan skala tinggi atau rendah beban kerja mental bisa berdasarkan subjektifitas seseorang. Menghitung WWL bertujuan untuk mendapatkan nilai dari beban kerja mental tiap faktor.

6. Pengkategorian Penilaian Beban Kerja

Kategori penilaian beban kerja terdiri dari tiga tingkatan, yaitu rendah dengan skala interval $0-9$, sedang dengan skala interval $10-29$, agak tinggi dengan skala interval $30-49$, tinggi dengan skala interval 50 - 79 dan sangat tinggi dengan skala interval $80-100$.

Untuk melihat sejauh mana potensi beban kerja dan produktivitas karyawan divisi BGES PT. Telkom Tbk di Bogor, dirasa penting untuk melakukan Penelitian ini mengingat fasilitas internet di sekolah-sekolah menjadi hal yang sangat penting. Terlebih di daerah Bogor masih banyak sekolah yang belum memiliki fasilitas internet padahal fasilitas ini sangat diperlukan dalam proses pembelajaran.

\section{METODE PENELITIAN}

Penelitian ini dilaksanakan di divisi BGES PT. Telkom. Penelitian berupa pengukuran beban kerja mental menggunakan metoda NASA-TLX. Pengukuran dilakukan terhadap karyawan Account Manager (AM). Pada divisi ini terdapat 12 karyawan AM, 3 karyawan AM government, 4 karyawan AM organik, dan 5 karyawan AM Pro. Tahapan umum pelaksanaan penelitian digambarkan pada Gambar 2 berikut:

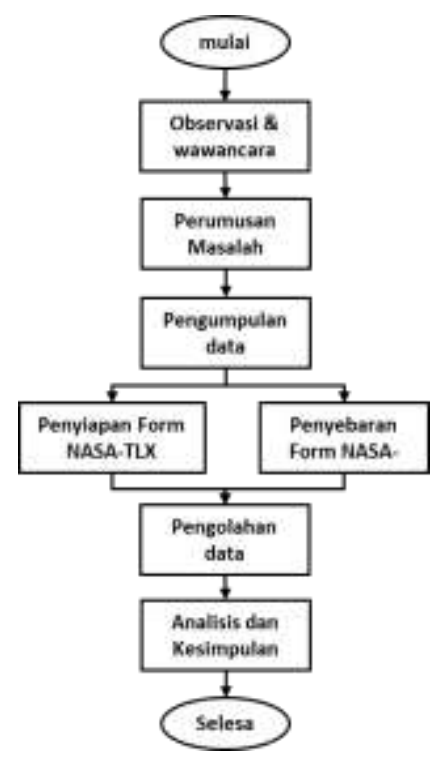

Gambar 2. Tahapan Penelitian

Penelitian dilakukan dengan mengikuti metodologi penggunaan NASA-TLX dalam pengukuran beban kerja.

\section{HASIL DAN PEMBAHASAN}

84 | Tingkat Beban Kerja Mental Karyawan Pada Layanan Business, Government, Enterprise (Bges) Bogor Pt. Telkom Indonesia Berdasarkan Metode Nasa-Tlx 
Setelah dilakukan penyebaran form NASA-TLX secara digital melalui link g-form, diperoleh hasil perbandingan berpasangan untuk setiap dimensi beban kerja dapat dilihat pada Gambar 3.

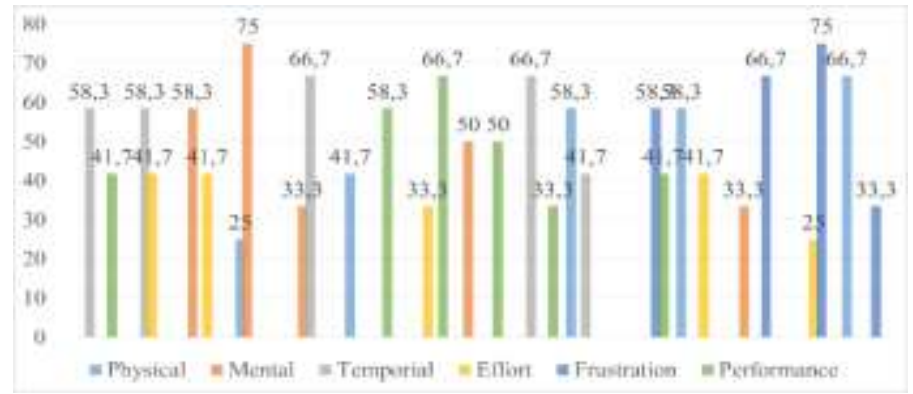

Gambar 3. Hasil perbandingan berpasangan

Dari hasil yang diperoleh, selanjutnya dilakukan pembobotan tiap faktor setelah dibandingkan dengan faktor yang lain. Hasil dari pembobotan adalah sebagai berikut seperti terlihat pada Tabel 2.

Tabel 2. Pembobotan hasil NASA-TLX

\begin{tabular}{|l|l|l|l|l|l|l|l|l|l|l|l|l|}
\hline \multirow{2}{*}{ Dimensi } & \multicolumn{10}{|c|}{ Respenden } \\
\cline { 2 - 14 } & 1 & 2 & 3 & 4 & 5 & 6 & 7 & 8 & 9 & 10 & 11 & 12 \\
\hline PD & 3 & 3 & 2 & 4 & 4 & 3 & 2 & 4 & 5 & 0 & 0 & 0 \\
\hline MD & 2 & 2 & 5 & 4 & 1 & 2 & 4 & 2 & 0 & 2 & 4 & 2 \\
\hline TD & 2 & 3 & 3 & 0 & 3 & 1 & 5 & 4 & 3 & 3 & 4 & 4 \\
\hline P & 4 & 2 & 3 & 2 & 3 & 2 & 0 & 2 & 2 & 4 & 2 & 3 \\
\hline E & 0 & 2 & 1 & 2 & 1 & 3 & 2 & 1 & 3 & 2 & 3 & 3 \\
\hline F & 4 & 3 & 1 & 3 & 3 & 4 & 2 & 2 & 2 & 4 & 2 & 3 \\
\hline Total & 15 & 15 & 15 & 15 & 15 & 15 & 15 & 15 & 15 & 15 & 15 & 15 \\
\hline
\end{tabular}

Langkah selanjutnya adalah melakukan pemberian rating dari tiap faktor dengan nilai satu sampai serratus seperti diperlihatkan pada Tabel 3.

Tabel 3. Hasil Rating setiap faktor

\begin{tabular}{|l|c|c|c|c|c|c|c|c|c|c|c|c|}
\hline \multirow{2}{*}{ Dimensi } & \multicolumn{10}{|c|}{ Responden } \\
\cline { 2 - 14 } & 1 & 2 & 3 & 4 & 5 & 6 & 7 & 8 & 9 & 10 & 11 & 12 \\
\hline PD & 50 & 65 & 70 & 55 & 80 & 80 & 65 & 85 & 85 & 65 & 65 & 65 \\
\hline MD & 75 & 55 & 75 & 65 & 75 & 75 & 70 & 70 & 75 & 80 & 70 & 75 \\
\hline ID & 60 & 70 & 75 & 75 & 75 & 80 & 85 & 80 & 75 & 75 & 75 & 85 \\
\hline P & 75 & 75 & 80 & 80 & 75 & 75 & 75 & 75 & 65 & 86 & 65 & 80 \\
\hline E & 70 & 60 & 75 & 75 & 75 & 75 & 60 & 75 & 70 & 80 & 80 & 85 \\
\hline F & 75 & 75 & 75 & 80 & 80 & 80 & 65 & 75 & 65 & 86 & 60 & 85 \\
\hline
\end{tabular}


Dari hasil pembobotan dan pemberian rating maka Weighted Workload (WWL) dapat dihitung seperti disampaikan pada Tabel 4.

Tabel 4. Hasil penentuan Weighted Workload

\begin{tabular}{|c|c|c|c|c|c|c|c|c|c|c|c|c|}
\hline \multirow{2}{*}{ Dimensi } & \multicolumn{12}{|c|}{ Responden } \\
\hline & 1 & 2 & 3 & 4 & 5 & 6 & 7 & 8 & 9 & 10 & II & 12 \\
\hline PD & 150 & 195 & 140 & 2201 & 320 & 240 & 130 & 340 & 425 & 0 & 0 & 0 \\
\hline MD & 150 & 110 & 375 & 260 & 75 & 150 & 280 & 140 & 0 & 160 & 280 & 150 \\
\hline TD & 120 & 210 & 225 & 0 & 225 & 80 & 425 & 320 & 225 & 225 & 300 & 340 \\
\hline $\mathrm{P}$ & 300 & 150 & 240 & 160 & 225 & 150 & 0 & 150 & 130 & 344 & 130 & 240 \\
\hline E & 0 & 120 & 75 & 150 & 75 & 225 & 120 & 75 & 210 & 160 & 240 & 255 \\
\hline $\mathrm{F}$ & 300 & 225 & 75 & 240 & 240 & 320 & 130 & 150 & 130 & 344 & 120 & 255 \\
\hline $\begin{array}{l}\text { Total } \\
\text { WWL }\end{array}$ & 1.020 & 1010 & I.130 & t.030 & 1.060 & 1.165 & 1,085 & L.175 & 1.120 & L.233 & 1.070 & 1.240 \\
\hline $\begin{array}{l}\text { Skor } \\
\text { WWL }\end{array}$ & 68 & 67.3 & 75,3 & 68,6 & $\pi 3$ & 77.6 & 723 & 78,3 & 74,6 & 82,2 & 71,3 & 82.6 \\
\hline
\end{tabular}

Pada tahap menghitung WWL (Tabel 4), nilai bobot setiap faktor dikalikan dengan nilai rating. Berikut merupakan contoh perhitungan dari WWL pada Responden 1:

$\mathrm{WWL}=$ nilai pembobotan $\times$ nilai rating

$\mathrm{WWL}=3 \times 50$

$\mathrm{WWL}=150$

Pada tahap menghitung Total WWL, nilai WWL pada setiap pegawai dijumlahkan sehingga mendapatkan nilai total WWL. Berikut merupakan contoh perhitungan dari Total WWL pada Responden 1:

Total WWL $=\Sigma$ Indikator

Total WWL $=(150+150+120+300+0+300$

Total WWL $=1.020$

Tahap menghitung skor WWL, nilai total WWL dibagi dengan jumlah pertanyaan yang terdapat pada kuesioner. Berikut merupakan contoh perhitungan dari skor WWL pada Responden 1:

Skor WWL = Total WWL/Jumlah Pembobotan

Skor WWL $=1.020 / 15$

Skor WWL $=68$

86 | Tingkat Beban Kerja Mental Karyawan Pada Layanan Business, Government, Enterprise (Bges) Bogor Pt. Telkom Indonesia Berdasarkan Metode Nasa-Tlx 
(Civil Engineeering, Elektrical Engineeering and Industrial Engineeering)

Vol. 16, No : 1, April 2019 , p-ISSN:1907-5243, e-ISSN: 2655-8416

Setelah menghitung total WWL dan skor WWL, langkah selanjutnya adalah melakukan pengkategorian penilaian beban kerja. Setiap posisi dalam divisi dihitung rata-rata skor WWL. Berikut merupakan contoh perhitungan rata-rata skor WWL untuk posisi AM Government:

Skor WWL $=\Sigma$ Skor AM government/Jumlah karyawan AM government

Skor WWL $=(82,2+71,3+82,6) / 3$

Skor WWL $=78,7$

Kategori beban kerja mempunyai beberapa tingkatan, yaitu rendah dengan skala interval 0 - 9, sedang dengan skala interval 10 - 29, agak tinggi dengan skala interval $30-49$, tinggi dengan skala interval $50-79$, dan sangat tinggi dengan interval $80-100$. Berikut ini merupakan hasil dari pengkategorian rata-rata penilaian beban kerja tiap indikator pada posisi AM Organik, AM Pro, dan AM Government:

Tabel 5. Penilaian kategori beban kerja

\begin{tabular}{|l|l|c|l|}
\hline No. & \multicolumn{1}{|c|}{ Posisi Divisi } & $\begin{array}{c}\text { Nilai Beban } \\
\text { Kerja }(\%)\end{array}$ & Kategori \\
\hline 1 & AM Organik & 73,8 & Tinggi \\
\hline 2 & AM Pro & 72,76 & Tinggi \\
\hline 3 & AM Government & 78,7 & Tinggi \\
\hline
\end{tabular}

Dari hasil perhitungan WWL dan pembobotan beban kerja mental berdasarkan dimensi pada NASA-TLX, seluruh dimensi memiliki nilai di atas 61 atau dikategorikan tinggi. Adapun dimensi paling tinggi adalah dimensi Temporal Demand (TD), Effort $(E)$, dan Frustration $(F)$ yaitu berturut-turut 75,8; 75,5 dan 75,1.

Terdapat beberapa faktor penyebab terjadinya beban kerja frustration, antara lain banyaknya tekanan pekerjaan dari perusahaan, kurangnya komunikasi dan motivasi, dan konflik dengan rekan kerja contohnya karena adanya perbedaan pendapat dengan rekan kerja yang membuat karyawan menjadi frustasi.

Untuk faktor physical demands dapat disebabkan oleh kegiatan yang mengharuskan karyawan melakukan perjalanan yang jauh dan kegiatan yang banyak seperti visit pelanggan, sosialisasi calon pelanggan di daerah kabupaten dan luar kota dalam waktu yang berdekatan.

Faktor temporial demands dapat disebabkan karena proyek kegiatan yang akan dilakukan harus dilakukan dalam periode yang tergolong singkat, sedangkan banyak hal yang perlu 
dilakukan dengan cepat dan cekatan sehingga ketersediaan waktu termasuk faktor yang mempengaruhi beban kerja mental karyawan BGES Telkom Bogor.

Beban kerja mental yang dirasakan oleh setiap kelompok AM dikategorikan tinggi, dengan nilai yang paling tinggi dirasakan oleh AM Government $(78,7 \%)$ sedangkan yang relatif paling rendah yaitu AM Pro (72,76\%) meskipun tetap dalam ketegori tinggi (> 61).

Dimensi frustration diperoleh nilai WWL tertinggi dirasakan oleh responden 10 sebesar 344. Untuk physical demands, nilai WWL tertinggi dirasakan oleh Responden 9 sebesar 425. Dimensi temporal demands, nilai WWL tertinggi dirasakan oleh Responden 7 sebesar 425.

Hasil penilaian Dimensi physical demands menunjukkan bahwa rata-rata karyawan BGES Telkom Bogor memberi nilai rating beban kerja sebesar 55,4\% yaitu tergolong sedang. Pada dimensi mental demands sebesar 71,6\%, yaitu tergolong tinggi, dan dimensi temporal demands sebesar $75,8 \%$, atau tergolong tinggi. Selanjutnya, dimensi performance memiliki nilai rating beban kerja sebesar 75,5\%, yaitu tergolong tinggi. Begitu pula pada dimensi effort sebesar 73,3\% yang dikategorikan tinggi. Terakhir pada dimensi frustration nilai rating beban kerja adalah sebesar $70,1 \%$, yang juga tergolong tinggi.

Perbaikan yang dapat dilakukan untuk menyeimbangkan beban kerja karyawan antara lain penambahan karyawan pada tiap divisi khususnya di bagian AM Government dikarenakan jumlah karyawan yang sedikit dan rata-rata skor beban kerja karyawannya tergolong paling tinggi, serta penjadwalan kegiatan yang membutuhkan kinerja fisik lebih seperti pergi ke luar kota, sosialiasi di kabupaten dan lain-lain agar jadwal tersebut tidak berdekatan dan menyebabkan kelelahan para karyawan yang dapat menyebabkan frustasi.

\section{Kesimpulan}

Penilaian tingkat beban kerja mental pada karyawan AM di divisi BGES PT. Telkom secara keseluruhan dikategorikan tinggi. Cakupan area layanan baik sebelum maupun after sales, dan juga penawaran layanan yang dilakukan oleh AM baik jadwal kunjungan maupun aktivitas ke luar kota saat ini menjadi faktor tingginya beban kerja yang dirasakan. Selain itu jumlah karyawan yang relatif sedikit juga mempengaruhi tingginya beban kerja. Hal ini dapat mempengaruhi produktivitas di masa yang akan datang. Saran yang diberikan atas hasil penilaian beban kerja ini adalah dengan menyeimbangkan beban kerja pada berbagai dimensi beban kerja mental. Hal ini dapat dilakukan dengan menambah karyawan, mengatur ulang jadwal kunjungan setiap karyawan, mengatur ulang jadwal tugas ke luar kota agar tidak berdekatan waktunya untuk menghindarkan beban kerja pada kategori Temporal demand (TD).

\section{UCAPAN TERIMAKASIH}

Ucapan terimakasih disampaikan pada Ibu Tri Suko Agustin, selaku Manager Business, Government, and Entersprise Telkom Bogor

88 | Tingkat Beban Kerja Mental Karyawan Pada Layanan Business, Government, Enterprise (Bges) Bogor Pt. Telkom Indonesia Berdasarkan Metode Nasa-Tlx 
(Civil Engineeering, Elektrical Engineeering and Industrial Engineeering)

Vol. 16, No : 1, April 2019 , p-ISSN:1907-5243, e-ISSN: 2655-8416

\section{DAFTAR PUSTAKA}

[1.] Latzer, Michael (2009), Information and communication technology innovations: radical and disruptive, New Media \& Society, Vol 11 (4), hal. 599-619

[2.] Biro Komunikasi dan Layanan Masyarakat; Mendikbud Terbitkan SE tentang Pelaksanaan Pendidikan dalam Masa Darurat Covid-19; https://www.kemdikbud.go.id/main/blog/2020/03/mendikbud-terbitkan-se-tentangpelaksanaan-pendidikan-dalam-masa-darurat-covid19

[3.] Priyono, \& Marnis. (2008). Manajemen Sumber Daya Manusia (1 ${ }^{\text {st }}$ ed.). Sidoarjo: Zifatama Publisher

[4.] Husein, Umar (2002). Evaluasi Kinerja Perusahaan. Jakarta : PT Gramedia Pustaka Utama

[5.] Hasibuan, Malayu. 2012. Manajemen Sumber Daya Manusia. Edisi Revisi. Bumi Aksara, Jakarta.

[6.] Wulanyani, Ni Made Swasti (2013), Tantangan dalam Mengungkap Beban Kerja Mental, Buletin Psikologi, Vol 21(2), hal 80-90

[7.] Handoko, T Hani. 2008. Manjemen Personalia. BPFE Yogyakarta, Yogyakarta.

[8.] Hidayat, T. F., Pujangkoro, S., \& Anizar. (2013). Pengukuran Beban Kerja Perawat Menggunakan Metode NASA-TLX di Rumah Sakit XYZ. e-Jurnal Teknik Industri, 2(1), 42-47.

[9.] Silvia., Hamdy, M. Ihsan;, Yusnil, R., (2018) Beban Kerja Mental Operator Mesin Dryer bagian Auto Clipper dengan Metode NASA-TLS (studi kasus: PT. ASIA Forestama Raya), Jurnal Teknik Industri, Vol 4(2), hal 83-90. 